\title{
An Overview of Indian Economy (1991-2013)
}

\author{
Namrata Anand \\ Research Scholar Department of Economics, Dayalbagh Educational Institute (Deemed University)
}

\begin{abstract}
Since 1951, India has fully-fledged as a planned economy. The first few plans focused on growth with strengthening of the manufacturing and industrial sector to form the backbone of the Indian economy. Other principal areas of planning were agriculture, poverty alleviation, employment generation, social development etc. Back in 1991, India saw itself battling its most critical economic and currency crisis ever, but after economic reforms and adopting the policy of LPG (Liberalization, Privatization, and Globalization) Indian economy performed well. Then again due to global financial crisis in 2008 Indian economy again interrupted and going through another turbulent phase. This paper analysis Indian economy from 1991-2013.
\end{abstract}

Key words: Indian Economy, Economic crisis, Global financial crisis.

The economy of India is the tenth largest in the world by nominal GDP and the third largest by purchasing power parity (PPP). The country is one of the G-20 major economies and a member of BRICS. On a per capita income basis, India ranked 140th by nominal GDP and 129th by GDP (PPP) in 2011, according to the IMF.

Back in 1991, India saw itself battling its most critical economic and currency crisis ever. The government then did not have many options but to take up some tough reforms. Many barriers and restrictions were taken off. The new economic policy of 1991 was characterized by liberalization, globalization and privatization. What followed these radical changes is now history.

Two decades have passed since then. And the ghosts of 1991 have come again to haunt us. Take the twin deficits during both these period. The fiscal deficit was at 5.39\% of GDP in 1991-92. In 2011-12 it was at 6.9\%. Similarly, the current account deficit was at 3\% of GDP in 1991. The same stood tall at 4.3\% in March 2012. Short term external debt has shot up from 10\% of GDP in 1991 to $22 \%$ currently. 1990s and 2000s witnessed major changes in the Indian economy due to economic liberalization in India. This revitalization took place in the whip of balance-of-payment emergency. The government of India allowed private infusions in Indian market which facilitated monetary infusion from FDI and FII. As per the estimate by Ministry of Statistics and Programme Implementation, GDP of India in the year 1990 stood at 5,542,706 in comparison with 842,210 in 1975.

Of course, it would be an overstatement to liken the current scenario to the 1991 crisis. The Indian economy has indeed come a long way since then. Back in 1991, India had foreign exchange that wouldn't last beyond two weeks. With current reserves of about US\$ 290 bn, the economy can meet its import requirements of about 7 months. India's domestic savings rate has gone up from $20 \%$ of GDP to $31.6 \%$ during this intervening period. Even Indian companies are in much better financial health today than in 1991.

But there are also several new challenges now that didn't exist back then. One very major difference is the state of the global economy. Back in 1991, the overall economic environment in the global arena was favourable. Today we are quite integrated with the global economy. This has tremendously increased our vulnerability to external shocks.

As a fledgling democracy, India's economic experiment of planned development was held out as an example to many aspiring low-income countries in the 1950s. While some countries raced ahead in the development process, India lagged behind. This is evident from the fact that it took 40 long years from 1950-51 for India's real per capita GDP to double by 1990-91. But, 1991-92 was a defining moment in India's modern economic history as a severe balance of payments (BOP) crisis prompted far reaching economic reforms, unlocking its growth potential.

\section{ECONOMIC PROGRESS POST-1991}

The initiation of economic reforms in the 1990s saw India gradually breaking free of the low growth trap which was euphemistically called the "Hindu growth rate" of 3.5 per cent per annum. Real GDP growth averaged 5.7 per cent per annum in the 1990s, which accelerated further to 7.3 per cent per annum in 2000s. A feature of the growth acceleration during the period was that while the growth rate of industry and services increased that of agriculture fell. This was because there was no notable technological breakthrough after the "green revolution" of the mid-1960s which saw sharp increase in yields of cereal production particularly in northern part of India. By the 1990s, the momentum of "green revolution" had died down. Consequently, the yield increases in the 2000s were much lower than those experienced even in the 1990s. Notably, the decade of 
the 2000s encompassed the inflexion point in the growth trajectory with an annual average GDP growth of about 9 per cent for the 5-year period 2004-08. Growth in all the sub-sectors of the economy, including agriculture, accelerated during this period. However, this growth process was interrupted by the global financial crisis. Subsequently, the average growth slowed down to 7.8 per cent during 2009-11 with a noticeable slowdown in both agriculture and industry. The slowdown in GDP growth in FY12 can mainly be attributed to high interest rates, inflation and a significant contraction in industrial production.

The growth dynamics altered the structure of the Indian economy with a decline in the share of agriculture from 28.4 per cent in the 1990s to about 15 per cent in 2009-11. There was corresponding gain in the share of services, including construction, from 52 per cent to 65 per cent during the same period. What is, however, of concern is that the share of industry has remained unchanged at around 20 per cent of GDP. This suggests that India's growth acceleration during the last two decades has been dominated by the services sector. The pace of average annual industrial growth had nevertheless picked up from 5.7 per cent during the 1990s to 9 per cent during 2004-08 before being interrupted by the global financial crisis.

\section{FIGURE-1}

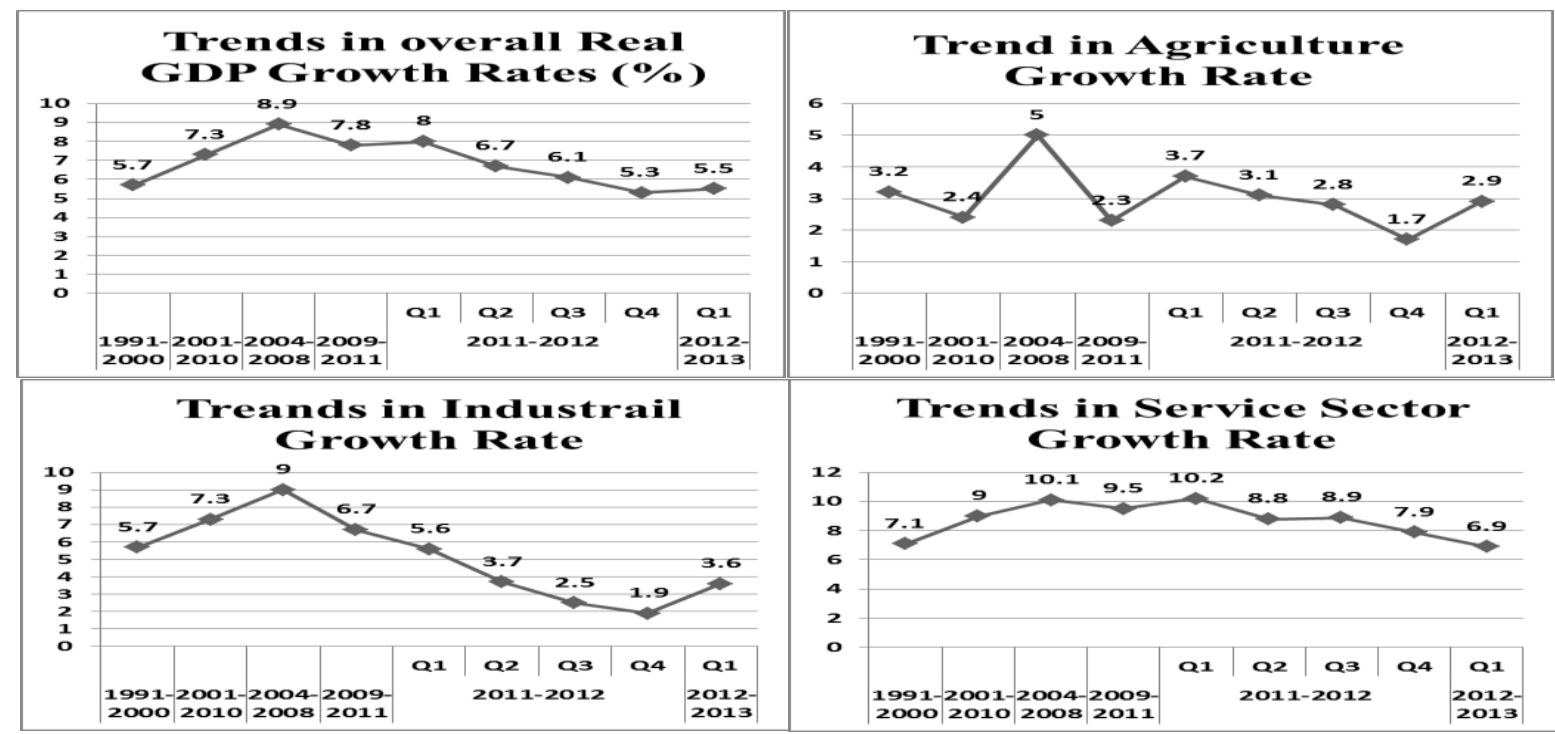

Source: Mohanty, D. Executive Director, Reserve Bank of India. September 2011.

While the share of industry in GDP remained stagnant, there was noteworthy structural transformation in manufacturing over the period. As a process of restructuring, while the gross value added in organized manufacturing increased by 8 per cent per annum at current prices, employment fell by 1.5 per cent per annum during 1995-2003. Subsequently, during 2004-09 gross value added growth accelerated to 20 per cent per annum at current prices; but significantly, employment also increased by 7.5 per cent per annum.

With work participation rate of 39.2 per cent, India had a workforce of 400 million in 2009-10. Of this, 53 per cent was in agriculture and the rest 47 per cent in non-agricultural activity. While the bulk of the employment is in agriculture despite its shrinking share, the noteworthy feature of the employment structure has been that for the first time the absolute workforce in agriculture declined in the latter half of the 2000s. The overall unemployment rate in the economy also declined from 8.3 per cent in 2004-05 to 6.6 per cent in 2009-10.

FIGURE -2

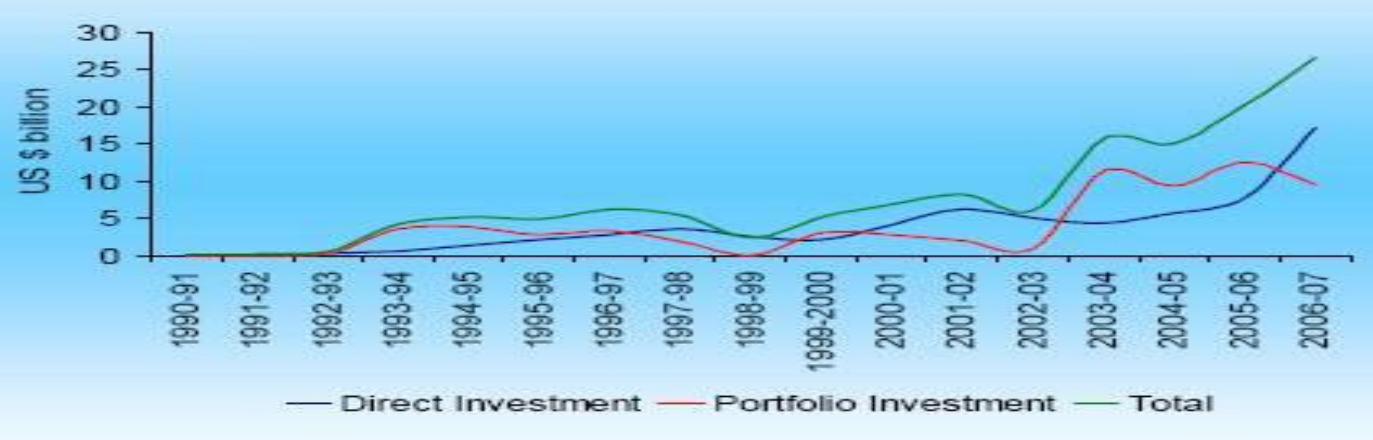


The attractiveness of India as a preferred investment destination could be ascertained from the large increase in FDI inflows to India, which rose continuously from year to year (Depicted in Figure 2). The significant increase in FDI inflows to India reflected the impact of liberalization of the economy since the early 1990s as well as gradual opening up of the capital account. As part of the capital account liberalization, FDI was gradually allowed in almost all sectors, except a few on grounds of strategic importance, subject to compliance of sector specific rules and regulations. FDI peaked in year FY 2007-08 and only marginally declined in the following years of economic crisis.

FIGURE-3

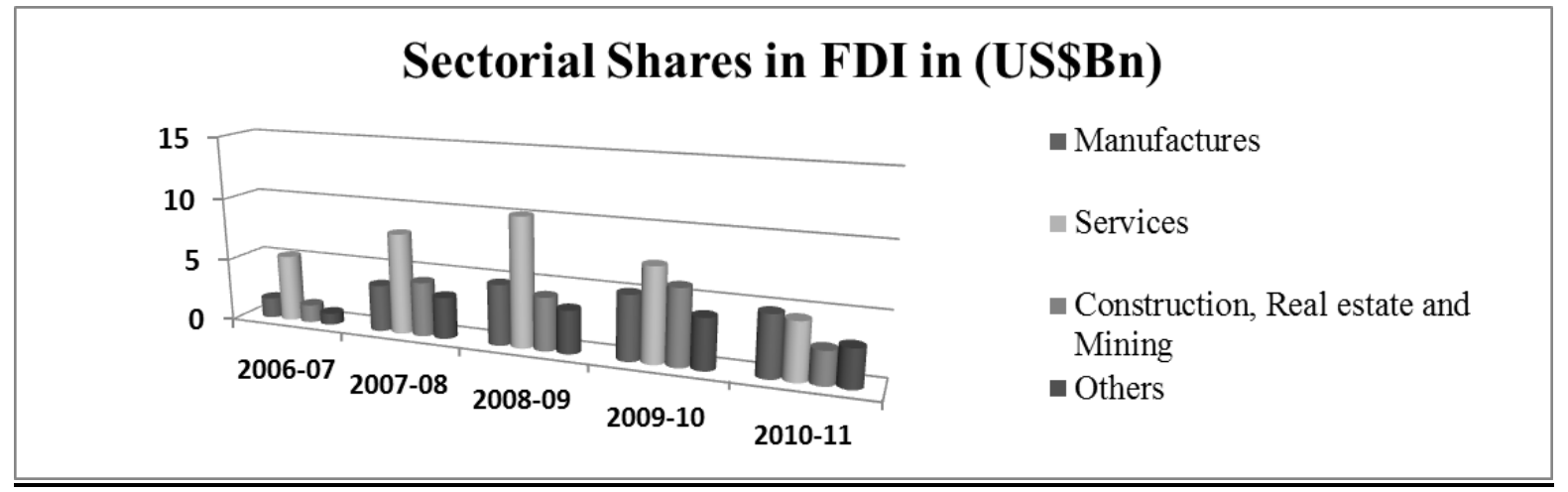

Source: Division of International Trade and Finance of the Department of Economic and Policy Research, Reserve Bank of India.

From a sectorial perspective, FDI in India mainly flowed into services sector (with an average share of 41 per cent in the past five years) followed by manufacturing (around 23\%). (See Figure 3). However, the share of services declined over the years from almost 57 per cent in 2006-07 to about 30 per cent in 2010-11 while the shares of manufacturing and others largely comprising electricity and other power generation increased over the same period.

\begin{tabular}{|l|l|l|l|l|l|l|l|l|}
\hline Countries & $\mathbf{2 0 0 4}$ & $\mathbf{2 0 0 5}$ & $\mathbf{2 0 0 6}$ & $\mathbf{2 0 0 7}$ & $\mathbf{2 0 0 8}$ & $\mathbf{2 0 0 9}$ & $\mathbf{2 0 1 0}$ & $\mathbf{2 0 1 1}$ (Jan-Sep) \\
\hline Mauritius & 26.7 & 48.5 & 43.9 & 40.3 & 42.8 & 42.7 & 34.3 & 34.2 \\
\hline Singapore & 1.7 & 7.4 & 7.6 & 7.6 & 11.4 & 11.3 & 10.1 & 15.4 \\
\hline U.S.A & 17.3 & 10.8 & 4.6 & 4.6 & 5.4 & 7.6 & 6.7 & 3.0 \\
\hline Japan & 3.1 & 3.9 & 3.5 & 3.5 & 1.2 & 4.7 & 6.2 & 9.7 \\
\hline Netherlands & 13.2 & 2.7 & 3.6 & 3.6 & 3.0 & 3.1 & 5.5 & 4.5 \\
\hline Cyprus & 0.1 & 1.6 & 2.8 & 2.8 & 4.0 & 6.0 & 4.4 & 4.0 \\
\hline Switzerland & 1.8 & 1.9 & 1.1 & 1.1 & 0.4 & 0.5 & 4.2 & 0.8 \\
\hline UK & 3.8 & 5.0 & 2.5 & 2.5 & 5.1 & 1.7 & 3.6 & 12.5 \\
\hline France & 3.1 & 0.7 & 0.7 & 0.7 & 1.4 & 1.1 & 3.6 & 2.0 \\
\hline Germany & 4.2 & 1.9 & 1.8 & 1.8 & 2.4 & 2.2 & 0.9 & 6.2 \\
\hline UAE & 0.8 & 1.1 & 1.1 & 1.1 & 0.9 & 2.3 & 1.7 & 0.7 \\
\hline Total(US\$bn) & 3.8 & 4.4 & 19.2 & 19.2 & 33.0 & 27.0 & 21.0 & 22.5 \\
\hline
\end{tabular}

Source: CEIC database, DIPP

The geographical spread of source countries for FDI in India is heavily skewed by tax rules. Mauritius has the highest share in total FDI inflows in India because of the Double Taxation Avoidance Treaty (DTAA) between the two countries. Apart from Mauritius, Singapore, and Cyprus have similar tax status, and they figure prominently on the list of source countries. FDI mainly routed through Mauritius (with an average share of 43 per cent in the past five years) followed by Singapore (around 11 per cent). FDI from Mauritius and Singapore recorded the largest decline in 2010, with inflows falling by 37 and 27 percent from 2009, respectively. FDI from the US, Germany, and Cyprus also saw declines, while FDI from European countries increased.

TABLE-2: WHOLESALE PRICE INDEX - ANNUAL AVERAGE

\begin{tabular}{|c|c|c|c|c|c|c|}
\hline \multirow{3}{*}{ Year } & \multirow{3}{*}{ AC } & \multirow{3}{*}{ PA } & \multirow{2}{*}{\multicolumn{2}{|c|}{ Of which }} & \multirow{3}{*}{ F\&P } & \multirow{3}{*}{ MP } \\
\hline & & & & & & \\
\hline & & & $\mathrm{FA}$ & NF & & \\
\hline 1 & 2 & 3 & 4 & 5 & 6 & 7 \\
\hline \multicolumn{7}{|c|}{ (Base: $1981-82=100$ ) } \\
\hline 1991-92 & 207.8 & 218.3 & 241.1 & 229.2 & 199.0 & 203.4 \\
\hline $1992-93$ & 228.7 & 234.6 & 271.0 & 228.7 & 227.1 & 225.6 \\
\hline 1993-94 & 247.8 & 250.9 & 284.4 & 249.1 & 262.4 & 243.2 \\
\hline
\end{tabular}


An Overview Of Indian Economy (1991-2013)

\begin{tabular}{|c|c|c|c|c|c|c|}
\hline 1993-94 & 100.0 & 100.0 & 100.0 & 100.0 & 100.0 & 100.0 \\
\hline 1994-95 & 112.6 & 115.8 & 112.8 & 124.2 & 108.9 & 112.3 \\
\hline $1995-96$ & 121.6 & 125.3 & 122.2 & 135.4 & 114.5 & 121.9 \\
\hline $1996-97$ & 127.2 & 135.8 & 137.2 & 134.2 & 126.4 & 124.4 \\
\hline $1997-98$ & 132.8 & 139.4 & 141.4 & 137.5 & 143.8 & 128.0 \\
\hline 1998-99 & 140.7 & 156.2 & 159.4 & 151.8 & 148.5 & 133.6 \\
\hline 1999-00 & 145.3 & 158.0 & 165.5 & 143.0 & 162.0 & 137.2 \\
\hline $2000-01$ & 155.7 & 162.5 & 170.5 & 146.5 & 208.1 & 141.7 \\
\hline 2001-02 & 161.3 & 168.4 & 176.1 & 152.9 & 226.7 & 144.3 \\
\hline 2002-03 & 166.8 & 174.0 & 179.2 & 165.4 & 239.2 & 148.1 \\
\hline 2003-04 & 175.9 & 181.5 & 181.5 & 186.3 & 254.5 & 156.5 \\
\hline 2004-05 & 187.3 & 188.1 & 186.3 & 187.6 & 280.2 & 166.3 \\
\hline \multicolumn{7}{|c|}{ (Base: $2004-05=100$ ) } \\
\hline 2005-06 & 104.5 & 104.3 & 105.4 & 96.7 & 113.6 & 102.4 \\
\hline 2006-07 & 111.4 & 114.3 & 115.5 & 102.3 & 120.9 & 108.2 \\
\hline 2007-08 & 116.6 & 123.9 & 123.6 & 114.4 & 121.0 & 113.4 \\
\hline 2008-09 & 128.0 & 137.5 & 134.8 & 129.2 & 135.0 & 120.4 \\
\hline 2009-10 & 130.8 & 154.9 & 155.8 & 136.2 & 132.1 & 123.1 \\
\hline 2010-11 & 143.3 & 182.4 & 179.6 & 166.6 & 148.3 & 130.1 \\
\hline 2011-12 & 156.1 & 200.3 & 192.7 & 182.7 & 169.0 & 139.5 \\
\hline 2012-13 & 167.6 & 220.0 & 211.8 & 201.9 & 186.5 & 147.1 \\
\hline
\end{tabular}

AC: All commodities

FA: Food articles

F\&P: Fuel and power

FA and NF are part of PA.

Source: Office of the Economic Adviser, Ministry of Commerce and Industry, Government of India

Table 2 shows the trends in inflation rate from 1991 to 2013. Currently as well as historically too, periods of high inflation has coincided with demand and/or supply-side shocks, with food (mostly internal, monsoon failures etc) and fuel supply (mostly external) shocks being the most persistent.

\section{FIGURE-4}

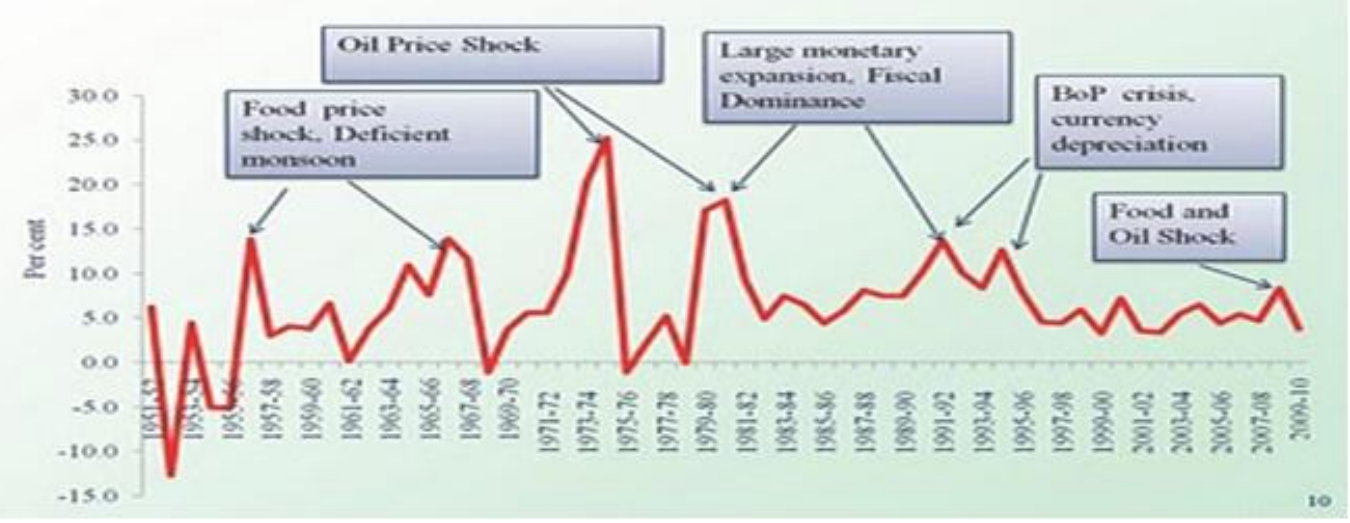

Decadal average inflation rates were dominated by primary goods and fuel (FPLL) inflation. Liberalization, and the effect of competition from abroad, reduced primary good and manufacturing inflation in 2000s, but the severe international food and oil price shocks pushed it up in the last years of the decade.

FIGURE-5

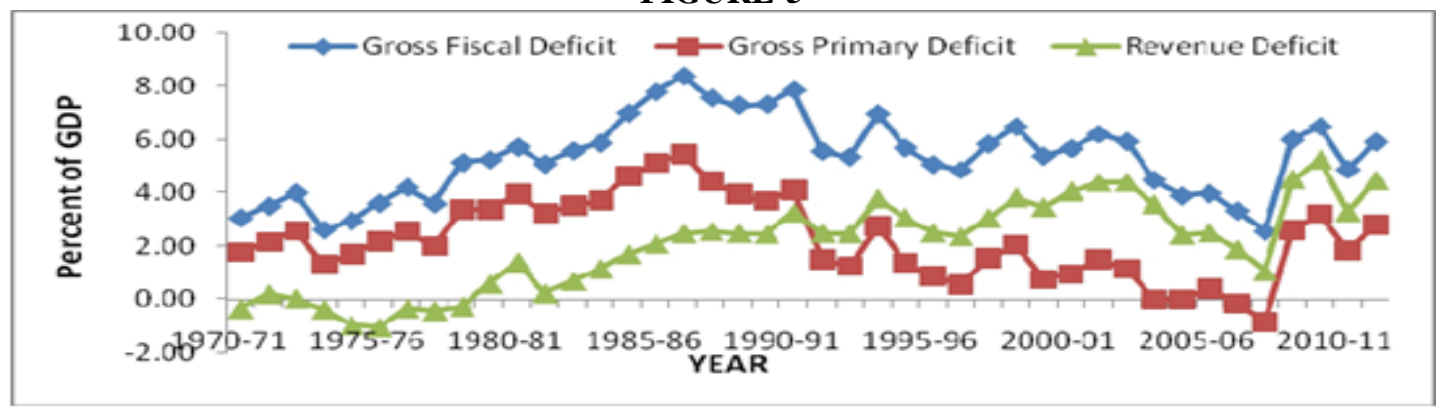

Source: Mohanty, R. K. (2012) 
Figure 5 traces the trends in deficits of central government over the past four decades. The gross fiscal deficit as a percent of Gross Domestic Product (GDP) increased from 3.04 percent of GDP in 1970-71 to the peak of 8.37 percent in 1986-87 and then declined to 4.84 percent in 1996-97. It was around 7 percent of GDP during 198788 to 1990-91. During the 1990s the average fiscal deficit as a percent of GDP was 5.67 percent. However, after 2003-04 central governments contained the fiscal deficit from 4.48 percent of GDP to its all-time minimum of 2.54 percent in the year 2007-08. Then it increased to 6.48 percent in 2009-10 and declined to 5.89 percent. Similarly primary deficit, which is fiscal deficit excluding interest payment has increased from 1.74 percent in 1970-71 to a peak of 5.43 percent in 1986-87 and declined to 0.53 percent of GDP in 1996-97. Primary deficit was dissolved from the year 2003-04 to the year 2007-08 except the year 2005-06. It was 2.78 percent during the year 2011-12.

After 1991-92, primary deficit has declined much due to the rising interest payment and to some extent a decline in fiscal deficit. Revenue deficit was incurred in the period 1971-72 and 1972-73. It was 0.57 percent in 197980, after that it increased to 3.26 percent in 1990-91. It reached maximum of 5.25 percent of GDP in 2009-10. The average of revenue deficit as a percentage of GDP in 1980s, 1990s and 2000s has been 1.72 percent, 3.02 percent and 3.40 percent respectively. It was 4.46 percent of GDP during the period 2011-12.

TABLE-3: EVOLUTION OF INDIA'S TRADE BALANCES (RS. CRORES)

\begin{tabular}{|l|l|l|l|l|}
\hline Period & Exports & Imports & Trade Balance & Trade balance as \% of GDP \\
\hline $\mathbf{1 9 9 1 - 9 2}$ & 32,553 & 43,198 & $-10,645$ & 2.1 \\
\hline $\mathbf{1 9 9 6 - 9 7}$ & 118,817 & 138,920 & $-20,103$ & 1.6 \\
\hline $\mathbf{1 9 9 7 - 9 8}$ & 130,100 & 154,176 & $-24,076$ & 1.7 \\
\hline $\mathbf{1 9 9 8 - 9 9}$ & 139,753 & 178,332 & $-38,580$ & 2.4 \\
\hline $\mathbf{1 9 9 9 - 0 0}$ & 159,561 & 215,236 & $-55,675$ & 3.1 \\
\hline $\mathbf{2 0 0 0 - 0 1}$ & 203,571 & 230,873 & $-27,302$ & 1.4 \\
\hline $\mathbf{2 0 0 1 - 0 2}$ & 209,018 & 245,200 & $-36,181$ & 1.7 \\
\hline $\mathbf{2 0 0 2 - 0 3}$ & 255,137 & 297,206 & $-42,069$ & 1.8 \\
\hline $\mathbf{2 0 0 3 - 0 4}$ & 293,367 & 359,108 & $-65,741$ & 2.6 \\
\hline $\mathbf{2 0 0 4 - 0 5}$ & 375,340 & 501,065 & $-125,725$ & 4.4 \\
\hline $\mathbf{2 0 0 5 - 0 6}$ & 456,418 & 660,409 & $-203,991$ & 6.2 \\
\hline $\mathbf{2 0 0 6 - 0 7}$ & 571,779 & 840,506 & $-268,727$ & 7.1 \\
\hline $\mathbf{2 0 0 0 7 - 0 8}$ & 655,864 & $1,0123,12$ & -356448 & 7.8 \\
\hline $\mathbf{2 0 0 0 8 - 0 9}$ & 840,755 & $1,374,436$ & $-533,680$ & 10.1 \\
\hline $\mathbf{2 0 0 9 - 1 0}$ & 845,534 & $1,363,736$ & $-518,202$ & 8.5 \\
\hline
\end{tabular}

Source: Economic Survey; Ministry of Finance, Government of India (2010-11

The rapid growth of demand for imports led to chronic current account deficit. It can be seen in Table 3 . The trade balance was negative in all years from 1991 to 2010. It peaked as a percentage of GDP in the years of India's first post-independence "balance of payments crises" in 1956-57 at 4.8 per cent of GDP, remained in the 3-4 per cent range in the 1960s, rose again as a response to the oil and commodity price increases of the early 1970s and again in that range in the 1980s.

\section{Conclusion:}

In conclusion we can say that Indian economy performed well after 1991 but currently Indian economy going through another turbulent phase. It is hard to believe the fact that, we have definitely grown since 1991 but the main imbalances then -fiscal deficit and current account deficit- are in reckoning again and have become the main concerns of today. People have started drawing parallels based on similarities in the economy like Current Account Deficit in 2012 is 4\% as compared to 3\% of 1991. Fiscal Deficit is 6\% in 2012 as compared to $8 \%$ in 1991.

[1]. Bhat, T. P. (2011). "Structural Changes in India's Foreign Trade" Retrieved on January 31, 2013 from http://isidev.nic.in/pdf/ICSSR_TPB.pdf

[2]. Mohanty, D. (Executive Director, Reserve Bank of India) (27 $7^{\text {th }}$ September 2011). "Indian Economy: Progress and Prospects", Retrieved on January 26, 2013 from http://www.bis.org/review/r110930b.pdf.

[3]. Mohanty, R. K. "Fiscal Deficit-Economic Growth Nexus in India: A Cointegration analysis", Retrieved on January 26, 2013. From http://www.punjabiuniversity.ac.in/cdeiswebsite/papers/30\%20Ranjan\%20Kumar\%20Mohanty\%20Fiscal\%20Deficit\%20Economic $\% 20$ Growth\%20Nexus\%20in\%20India\%20A\%20Cointegration\%20analysis.final.pdf.

[4]. The World Bank. (2012) "Indian Economic Update" Retrieved on February 03, 2013. From http://siteresources.worldbank.org/INDIAEXTN/Resources/295583-1328744264781/India_Economic_Updata_March2012.pdf

[5]. US India Business Council (2012) "India Foreign Direct Investment Trends India continues to provide opportunities in a challenging environment" Retrieved on February 01, 2013. From http://www.cedarconsulting.com/pdf/Cedar_USIBC_\%20Report.pdf 
[6]. Department of Economic Affairs (Government of India).

[7]. Gulzar (October 13, 2010). "Analysing inflation trends in India" Retrieved on February 03, 2013. From http://gulzar05.blogspot.in/2010/10/analysing-inflation-trends-in-india.html

[8]. Goyal, A. (September 2011) "History of Monetary Policy in India since Independence" Retrieved on February 02, 2013. From http://www.igidr.ac.in/pdf/publication/WP-2011-018.pdf.

[9]. India BIZNEWS (December 22, 2011) "Trends in FDI in India" Retrieved on February 04, 2013. From http://www.indiabiznews.com/?q=node/2222

[10]. Reserve Bank of India (May 10, 2012) "Foreign Direct Investment Flows to India" Retrieved on February 05, 2013 from http://www.rbi.org.in/scripts/BS_ViewBulletin.aspx?Id=13224.

[11]. “1991 to 2012: Has India come full circle?" (June 01, 2012) Retrieved on February 03, 2013 from http://www.equitymaster.com/5MinWrapUp/detail.asp?date=06/01/2012\&story=6\&title=1991-to-2012-Has-India-come-full-circle

[12]. Wikipedia The free Encyclopedia "Economy of India" (July 16, 2012). Retrieved on February 04, 2013. From http://en.wikipedia.org/wiki/Economy_of_India. 